\title{
Ameliorative potential of whey protein hydrolysate against paracetamol-induced oxidative stress
}

\author{
S. Athira, Bimlesh Mann, ${ }^{1}$ Rajan Sharma, and Rajesh Kumar \\ Dairy Chemistry Division, National Dairy Research Institute, India 132001
}

\begin{abstract}
The aim of the present study was to validate the antioxidant effect of whey protein hydrolysate (WPH) using a small animal model. Paracetamol is common drug that is safe at therapeutic levels; however, an overdose causes oxidative stress, which may lead to potential hepatic and renal necrosis. The protective effect of WPH against paracetamol-induced hepato-nephrotoxicity in mice was investigated in this study. The WPH was prepared by hydrolyzing ultrafiltered retentate of mozzarella cheese whey with commercial food-grade alcalase; the resulting WPH had substantial in vitro antioxidant activity. Male albino mice were treated with WPH for $4 \mathrm{~d}$ [intraperitoneally at $4 \mathrm{mg} / \mathrm{kg}$ of body weight (BW) per day or orally at $8 \mathrm{mg} / \mathrm{kg}$ of BW per day] before or after oral administration of paracetamol (300 mg/ $\mathrm{kg}$ of $\mathrm{BW}$ ) for $2 \mathrm{~d}$. Two control groups were used; the negative control mice were administered water only; the paracetamol group was administered paracetamol at $300 \mathrm{mg} / \mathrm{kg}$ of BW but received no WPH. Levels of different marker enzymes (glutamate pyruvate transaminase and alkaline phosphatase), creatinine, and blood urea nitrogen were measured in the experimental animal blood sera. The WPH successfully mitigated the increase in the concentration of oxidative biomarkers such as glutathione pyruvate transaminase, alkaline phosphatase, and creatinine, and restored the level of blood urea nitrogen to normal in sera of mice in which oxidative stress was induced with an overdose of paracetamol. Furthermore, the indices of different antioxidant enzymes, such as catalase, superoxide dismutase, and glutathione peroxidase, and lipid peroxidation end-products were determined in liver homogenate. The mice that were given WPH, either intraperitoneally or orally, showed increased activities of antioxidant enzymes and a reduction in thiobarbituric acid reactive substances (TBARS) compared with the paracetamol control group. The protective effect of WPH was less when administered orally than intraperitoneally. We
\end{abstract}

Received August 24, 2012.

Accepted November 12, 2012.

${ }^{1}$ Corresponding author: bimleshmann@gmail.com concluded that WPH is the potential protector against paracetamol-induced hepato-nephrotoxicity and can be effectively used in health-promoting foods as a biofunctional ingredient.

Key words: oxidative stress, paracetamol, antioxidant, whey protein hydrolysate

\section{INTRODUCTION}

Oxidative stress, the increased production of reactive oxygen species (ROS) and reactive nitrogen species (RNS), combined with overtaking endogenous antioxidant defense mechanisms, is a significant causative factor for the initiation or progression of several lifestylemediated diseases (Moskovitz et al., 2002). One of the main causes of oxidative stress is the overdose of clinically useful drugs, which can lead to cellular damage after metabolic activation to highly reactive compounds. Paracetamol is a drug of the para-aminophenol group commonly used for analgesic and antipyretic purposes. The drug is safe at therapeutic levels, but an acute paracetamol overdose can lead to potentially fatal hepatic and renal necrosis in humans and experimental animals (Proudfoot and Wright, 1970). It is becoming clear that ROS and RNS play an important part in the development of hepatotoxicity caused by paracetamol (Michael et al., 1999). The initial step of its toxicity is cytochrome P450 (CYP 450) metabolism of paracetamol to the reactive intermediate $N$-acetyl- $p$ benzoquinone imine (NAPQI; Dahlin et al., 1984). At therapeutic doses, this metabolite is removed by conjugation with glutathione (GSH) and eliminated via the kidneys. However, at large doses of paracetamol, production of NAPQI overloads the capacity of GSH to detoxify it. The excess NAPQI then causes liver damage associated with oxidative stress (Mitchell et al., 1973). Paracetamol-induced toxicity leads to an increase in the levels of serum marker enzymes, such as glutamate pyruvate transaminase (GPT) and alkaline phosphatase (ALP), and amino acid oxidation products, such as creatinine and BUN. Measurement of biochemical parameters including GPT, ALP, creatinine, and BUN; the antioxidant enzymes catalase (CAT), superoxide dismutase (SOD), and glutathione peroxi- 
dase (GSHPx); and lipid peroxidation end-products (e.g., malondialdehyde) in biological samples are widely used to determine the state of oxidative stress (Ghosh and Sil, 2007).

Dietary consumption of antioxidants appears to benefit endogenous antioxidant defense strategies in the fight against oxidative stress (Fang et al., 2002). Recent studies have shown that peptides having antioxidant properties can be released from milk proteins (Hernandez-Ledesma et al., 2005). The exact mechanism underlying the antioxidant activity of peptides is not fully understood, yet various studies indicate that these peptides are inhibitors of lipid peroxidation, scavengers of free radicals, and chelators of transition metal ions (Rajapakse et al., 2005; Moure et al., 2006; Qian et al., 2008). In addition, antioxidative peptides keep cells safe from damage by ROS through the induction of genes (Rajapakse et al., 2005).

Adriena et al. (2010) measured antioxidant activity [expressed as percentage scavenging of the 2,2'-azinobis-(3-ethylbenzothiazoline-6-sulfonic acid) radical] of the whey proteins and their hydrolysates and reported that unhydrolyzed whey protein showed low antioxidant activity (7-19.8\%), whereas upon hydrolysis with microbial proteases (alcalase, flavorzyme, protamex, and neutrase), the values increased notably (40-54.2\%) with all tested hydrolysates. Hernandez-Ledesma et al. (2005) investigated the antioxidant activity of hydrolysates from $\alpha-\mathrm{LA}$ and $\beta-\mathrm{LG}$ by commercial proteases (pepsin, trypsin, chymotrypsin, thermolysin, and corolase PP). Whey protein isolate was hydrolyzed for 0.5 to $8 \mathrm{~h}$ using alcalase and the results indicated that the antioxidant activity of whey protein hydrolysates (WPH) depended on peptide molecular weight, with peptides of 0.1 to $2.8 \mathrm{kDa}$ possessing the strongest radical-scavenging activity (Xinyan et al., 2009).

The aim of the present study was to evaluate the antioxidant effects of WPH in paracetamol-induced toxicity in mice by measuring the level of GPT, ALP, creatinine, and BUN in the blood serum of the experimental mice groups. The extent of lipid peroxidation and activities of the endogenous antioxidant enzymes SOD, CAT, and GSHPx were measured in the liver homogenates of treated and untreated mice.

\section{MATERIALS AND METHODS}

\section{Chemicals}

The enzyme alcalase was obtained from Novozyme (Bangalore, India). Paracetamol (Paramol 500, Pharmaceutical Industries India Pvt. Ltd., Mumbai, India) was obtained from a local medical store (Karnal, India). Kits for the measurement of serum GPT and ALP were purchased from Span Diagnostics Ltd. (Surat, India), and kits for creatinine and BUN measurement in blood serum were purchased from Erba Diagnostics (Mannheim, Germany) and Techno Pharmchem (Delhi, India) respectively. All other chemicals were purchased from Sisco Research Laboratories Pvt. Ltd. (Mumbai, India), Loba Chemie Pvt. Ltd. (Mumbai, India), and Himedia Laboratories Pvt. Ltd. (Mumbai, India).

\section{Preparation of WPH}

Mozzarella cheese whey was collected from the experimental dairy of the National Dairy Research Institute (Karnal, India) and subjected to ultrafiltration to concentrate the protein content. After preheating at $70^{\circ} \mathrm{C}$ for $10 \mathrm{~min}$, the retentate was hydrolyzed at between 55 and $60^{\circ} \mathrm{C}, \mathrm{pH}$ between 8 and 9 , and hydrolysis time of about $8 \mathrm{~h}$ using commercial food-grade alcalase. Whey protein hydrolysate with $73.90 \pm 0.30 \%$ protein prepared using optimized conditions showed an antioxidant activity of $1.18 \pm 0.015 \mu \mathrm{mol}$ of Trolox $/ \mathrm{mg}$ of protein (Athira, 2012).

\section{Animals and Experimental Design}

A total of 24 Swiss albino male mice weighing 25 to $35 \mathrm{~g}$ were obtained from the small animal house facility of National Dairy Research Institute. They were housed in groups of 6 in polypropylene cages with stainless steel, wire-bar lids using rice husks as a bedding material under a 12-h light:dark cycle and room temperature of 22 to $24^{\circ} \mathrm{C}$. Mice were acclimatized to the environment for $1 \mathrm{wk}$ before the experiment. All had free access to a standard basal diet and water ad libitum. The study was approved by the Institutional Animal Ethics Committee (IAEC).

Experimental groups were as follows: (1) intraperitoneal injection of water for $4 \mathrm{~d}$ followed by oral feeding of water for $2 \mathrm{~d}$ (control); (2) intraperitoneal injection of water for $4 \mathrm{~d}$ followed by oral administration of paracetamol at $300 \mathrm{mg} / \mathrm{kg}$ of BW for $2 \mathrm{~d}$ (paracetamol control); (3) intraperitoneal injection of WPH at $4 \mathrm{mg} /$ $\mathrm{kg}$ of $\mathrm{BW}$ for $4 \mathrm{~d}$ followed by oral administration of paracetamol at $300 \mathrm{mg} / \mathrm{kg}$ of BW for $2 \mathrm{~d}$ (preventive); (4) oral administration of paracetamol at $300 \mathrm{mg} / \mathrm{kg}$ of BW for $2 \mathrm{~d}$ followed by intraperitoneal injection of WPH at $4 \mathrm{mg} / \mathrm{kg}$ of BW for $4 \mathrm{~d}$ (curative); and (5) oral administration of WPH at $8 \mathrm{mg} / \mathrm{kg}$ of BW for $4 \mathrm{~d}$, followed by oral administration of paracetamol at 300 $\mathrm{mg} / \mathrm{kg}$ of BW for $2 \mathrm{~d}$ (oral).

\section{Collection and Processing of Blood}

On d 7, mice were killed by exposing them to chloroform for a brief period followed by cervical disloca- 
tion. Using a 1-mL syringe, blood was drawn from the heart and collected in storage vials (plain tubes with no anticoagulant). Vials were kept overnight at room temperature to clot and then centrifuged at 3,000 $\times g$ for $10 \mathrm{~min}$. Serum was collected in separate vials and used for analysis of different oxidative biomarkers.

\section{Analysis of Blood Serum for Oxidative Biomarkers}

The analyses were done using commercially available blood testing kits: GPT was measured by the dinitrophenyl hydrazine (2,4 DNPH) method of Reitman and Frankel (1957) and its activity was expressed in international units per liter. Alkaline phosphatase was estimated by the Kind and King (1954) method using phenyl phosphate substrate and expressed as King and Armstrong Unit (KAU, the quantity of alkaline phosphatase that acting upon disodium phenyl phosphate in excess at $\mathrm{pH} 9$ for $30 \mathrm{~min}$ liberates $1 \mathrm{mg}$ of phenol; $7 \mathrm{KAU} / \mathrm{dL}=1 \mathrm{IU} / \mathrm{L}$ ). Creatinine was measured according to the method of Bones and Tausky (1945), and BUN was determined spectrophotometrically from serum samples using the diacetylmonooxime method (Marsh et al., 1965; Crocker, 1967). Both creatinine and BUN was expressed in milligrams per deciliter.

\section{Collection of Liver and Preparation of Liver Homogenate}

The mice were dissected and the entire liver was excised, washed with isotonic buffer ( $\mathrm{pH} 7.4)$, and stored at $-80^{\circ} \mathrm{C}$. For preparation of liver homogenate, the liver was weighed and homogenized in 10 volumes of isotonic buffer. The homogenate was centrifuged at 3,000 $\times g$ for $10 \mathrm{~min}$ to remove nuclei and cell debris.

\section{Analysis of Liver Homogenate}

Activity of CAT was estimated spectrophotometrically by the method of Aebi (1984), in which a decrease in absorbance at $240 \mathrm{~nm}$ due to decomposition of $\mathrm{H}_{2} \mathrm{O}_{2}$ by the action of CAT was measured using a spectrophotometer (Specord Analytik Jena, Jena, Germany). The difference in absorbance $\left(\Delta \mathrm{A}_{240}\right)$ per unit time was the measure of CAT activity and was expressed as units per milligram of protein. Superoxide dismutase was assayed by the method of Marklund and Marklund (1974) using inhibition of pyrogallol autooxidation by SOD. One unit of enzyme was defined as the amount of enzyme that inhibited the reaction by 50\%. Enzyme activity was expressed in units per milligram of protein in liver homogenate. Glutathione peroxidase was estimated spectrophotometrically using the method of Lawrence and Burk (1976) and expressed as nanomoles of NADPH oxidized per minute per milligram of protein or unit per milligram of protein using an extinction coefficient of $6.22 \times 10^{-3} \mathrm{~L} / \mathrm{mol}$ per $\mathrm{cm}$. For detection of lipid peroxides (malondialdehyde), in terms of thiobarbituric acid reactive substances (TBARS) in liver homogenate, the method of Mihara and Uchiyama (1978) was followed and results expressed as micromoles of malonaldehyde per milligram of protein. Protein content in liver homogenates was estimated according to the method of Lowry et al. (1951) using BSA as standard.

\section{Statistical Analysis}

All results are expressed as mean \pm standard error (SE). Significance was tested by using ANOVA, the level of statistical significance for all comparisons made was established at $P \leq 0.05$, and comparison between means was made by critical difference (CD).

\section{RESULTS AND DISCUSSION}

\section{Analysis of Oxidative Biomarkers}

Glutamate pyruvate transaminase, also called alanine transaminase (ALT), is an enzyme found in liver, serum, and various tissues. High levels of ALT released in the blood may be a sign of liver damage (Wang et al., 2012). Elevated ALP serum levels can indicate a number of diseases, including those associated with liver, bile duct, and bone (Stockham and Scott, 2002). Creatinine is a waste product found in muscle tissues from the high-energy storage compound creatinine phosphate. Elevated serum creatinine is usually associated with various renal diseases (Bowers, 1980). As shown in Table 1, serum GPT, ALP, and creatinine levels of mice treated with paracetamol $(8.92 \pm 0.27 \mathrm{IU} / \mathrm{L}, 5.94 \pm$ $0.45 \mathrm{KAU}$, and $0.94 \pm 0.04 \mathrm{mg} / \mathrm{dL}$, respectively) were significantly higher than those of control group (2.03 $\pm 0.32 \mathrm{IU} / \mathrm{L}, 4.22 \pm 0.33 \mathrm{KAU}$, and $0.24 \pm 0.07 \mathrm{mg} /$ $\mathrm{dL}$, respectively). The increases in serum GPT, ALP, and creatinine in the mice groups fed an overdose of paracetamol $(300 \mathrm{mg} / \mathrm{kg}$ of $\mathrm{BW})$ indicate hepatocellular necrosis and nephrotoxicity. These results were supported by Ghosh and Sil (2007), who also observed elevated levels of these enzymes upon treatment of mice with an overdose of paracetamol. Oxidative stress is a major contributor in pathogenesis of paracetamolinduced liver and renal damage in experimental animals (Ghosh et al., 2010; Parmar et al., 2010). Administration of WPH (4 mg/ $\mathrm{kg}$ of BW) by intraperitoneal injection before and after paracetamol administration significantly $(P<0.05)$ lowered the levels of GPT, ALP, and creatinine in the serum. The levels of GPT, ALP, and creatinine also decreased significantly $(P<$ 
Table 1. The level of serum marker enzymes glutamate pyruvate transaminase (GPT), alkaline phosphatase (ALP), creatinine, and BUN from the blood serum of different groups of mice ${ }^{1}$

\begin{tabular}{|c|c|c|c|c|c|}
\hline \multirow[b]{2}{*}{ Parameter } & \multirow[b]{2}{*}{ Control } & \multirow[b]{2}{*}{ Paracetamol } & \multicolumn{2}{|c|}{ Intraperitoneal injection } & \multirow[b]{2}{*}{ Oral } \\
\hline & & & Preventive & Curative & \\
\hline GPT (IU/L) & $2.03 \pm 0.32^{\mathrm{a}}$ & $8.92 \pm 0.27^{\mathrm{e}}$ & $4.11 \pm 0.56^{\mathrm{c}}$ & $2.77 \pm 0.27^{\mathrm{b}}$ & $4.43 \pm 0.78^{\mathrm{d}}$ \\
\hline $\mathrm{ALP}\left(\mathrm{KAU}^{2}\right)$ & $4.22 \pm 0.33^{\mathrm{b}}$ & $5.94 \pm 0.45^{\mathrm{d}}$ & $3.57 \pm 0.39^{\mathrm{a}}$ & $4.06 \pm 0.27^{\mathrm{b}}$ & $4.64 \pm 0.27^{\mathrm{c}}$ \\
\hline Creatinine $(\mathrm{mg} / \mathrm{dL})$ & $0.24 \pm 0.07^{\mathrm{a}}$ & $0.94 \pm 0.04^{\mathrm{d}}$ & $0.39 \pm 0.09^{\mathrm{b}}$ & $0.38 \pm 0.04^{\mathrm{b}}$ & $0.61 \pm 0.02^{\mathrm{c}}$ \\
\hline BUN $(\mathrm{mg} / \mathrm{dL})$ & $20.52 \pm 0.67^{\mathrm{c}}$ & $13.85 \pm 1.20^{\mathrm{a}}$ & $17.09 \pm 1.03^{\mathrm{b}}$ & $20.01 \pm 1.22^{\mathrm{c}}$ & $17.97 \pm 1.55^{\mathrm{b}}$ \\
\hline \multicolumn{6}{|c|}{${ }^{\mathrm{a}-\mathrm{e}}$ Means within a row with different superscripts differ $(P<0.05)$} \\
\hline \multicolumn{6}{|c|}{$\begin{array}{l}{ }^{1} \text { Control }=\text { untreated control mice; paracetamol = mice overdosed with paracetamol at a } 300 \mathrm{mg} / \mathrm{kg} \text { of } \mathrm{BW} \\
\text { for } 2 \mathrm{~d} \text {; intraperitoneal injection = whey protein hydrolysate }(\mathrm{WPH}) \text { administered by intraperitoneal injection } \\
\text { at } 4 \mathrm{mg} / \mathrm{kg} \text { of } \mathrm{BW} \text { for } 4 \mathrm{~d} \text { before (preventive) or } 4 \mathrm{~d} \text { after (curative) paracetamol administration; oral = WPH } \\
\text { given orally at } 8 \mathrm{mg} / \mathrm{kg} \text { of } \mathrm{BW} \text { for } 4 \mathrm{~d} \text { before paracetamol administration. }\end{array}$} \\
\hline \multicolumn{6}{|c|}{$\begin{array}{l}{ }^{2} \mathrm{KAU}=\text { King and Armstrong Unit; the quantity of alkaline phosphatase that acting upon disodium phenyl } \\
\text { phosphate in excess at } \mathrm{pH} 9 \text { for } 30 \mathrm{~min} \text { liberates } 1 \mathrm{mg} \text { of phenol; } 7 \mathrm{KAU} / \mathrm{dL}=1 \mathrm{IU} / \mathrm{L} \text {. }\end{array}$} \\
\hline
\end{tabular}

$0.05)$ in serum of mice orally administered WPH (8 $\mathrm{mg} / \mathrm{kg}$ of BW) after application of paracetamol. The reduction in GPT, ALP and creatinine levels (Table 1) in serum following intraperitoneal (preventive and curative groups) and oral treatment with WPH established the antioxidant effect in vivo. However, the decrease in GPT, ALP and creatinine levels in the oral WPH group was significantly smaller than that of the preventive and curative groups (treated intraperitoneally; Table 1). Similar observations were made by Yousef et al. (2010), in that the antioxidants curcumin and quercetin successfully restored liver function and inhibited oxidative stress induced by paracetamol. Singh et al. (2011) also reported that quercetin has protective activity against paracetamol-induced hepatic and renal injuries in mice. Some studies have been conducted to establish the protective effect of intact whey protein on damaged liver cells. Zeinab et al. (2007) reported that activities of the liver enzymes ALP, ALT, and aspartate aminotransferase (AST) of rats fed an aflatoxin-contaminated diet were significantly increased in plasma. The increase in activities of the liver enzymes may be due to liver damage and release of these enzymes into the circulation (Lynch et al., 1971). Supplementation with whey protein concentrate in the diet minimized that increase in the activity of the enzymes, indicating the protective action of whey proteins on liver cells. Similarly, Ahmed et al. (2010) observed increases in the levels of ALT, AST, and ALP in rats fed an aflatoxincontaminated diet, and treatment with WPC showed significant improvements in the levels of these markers (toward control values) although treatment failed to fully normalize levels. In a clinical study, Watanabe et al. (2000) found that serum ALT activity was reduced in 6 of 8 patients with chronic hepatitis B by feeding a diet supplemented with whey proteins for 12 wk.

It has been reported (Gregory, 2003) that BUN is an indirect and approximate measurement of renal and liver functioning. After ingestion, protein is broken down into amino acids, which are catabolized in the liver and ammonia is formed. The ammonia molecules combine to form urea, which is then deposited in the blood and transported to the kidneys for excretion. Higher than normal levels of serum BUN indicate malfunctioning of kidneys, whereas lower levels of serum BUN indicate liver disease or damage or malnutrition (Gregory, 2003; Waring et al., 2008). In our findings, serum BUN level in the paracetamol group was lower than that of the control group (13.85 \pm 1.20 vs. $20.52 \pm 0.67 \mathrm{mg} / \mathrm{dL}$ ). Similarly, Waring et al. (2008) reported that BUN is decreased in the serum of mice administered paracetamol, which may be due to paracetamol-induced hepatotoxicity. However, in the current study, when WPH was administered orally and intraperitoneally (preventive and curative groups), BUN increased to normal in the curative group (20.01 $\pm 1.22 \mathrm{mg} / \mathrm{dL}$ ), was slightly lower in the preventive $(17.09 \pm 1.03 \mathrm{mg} / \mathrm{dL})$ and oral $(17.97 \pm 1.55 \mathrm{mg} / \mathrm{dL})$ groups compared with the control group, but was significantly higher than in the paracetamol (control, no WPH) group of mice (Table 1). Our interpretation of these results is that administration of WPH mitigated the paracetamol-induced toxicity in both the preventive and curative groups.

\section{Analysis of Liver Homogenate}

The activities of endogenous antioxidant enzymes CAT, SOD, and GSHPx in liver homogenate of the treated and untreated mice are shown in Table 2. Activities of CAT, SOD, and GSHPx in the paracetamol group decreased by 30,18 , and $42 \%$, respectively, compared with the control group. The basic mechanism of paracetamol toxicity in the liver is the covalent binding of NAPQI, the reactive metabolite of paracetamol, to sulfhydryl groups of glutathione (GSH), causing their 
subsequent oxidation (Lee et al., 2003). On the other hand, several mechanisms have been suggested as probable pathways for paracetamol-mediated nephrotoxicity, which also involve hepatically derived metabolites from paracetamol-GSH conjugates (Trumper et al., 1998). Yousef et al. (2010) reported that paracetamol treatment caused a significant elevation in TBARS levels with simultaneous inhibition in the activities of antioxidant enzymes; namely, glutathione S-transferase (GST), GSHPx, SOD, and CAT in rat plasma, liver, kidney, brain, lung, heart, and testis. These features might be attributed to the metabolic activation of paracetamol, which is considered a major mechanism of its toxicity. Paracetamol was found to trigger a rapid loss of GSH and increased lipid peroxidation in both liver (Jaeschke et al., 2003) and kidney (Newton et al., 1986). The decrease in SOD and CAT activities in the current study indicated a decrease in the antioxidative capacity as well. The decreased activity of SOD may be attributed to the consumption of these enzymes in ROS detoxification (Mladenovic et al., 2009). Superoxide dismutase is inhibited by hydrogen peroxide, whereas GSHPx and CAT are inhibited by an excess of superoxide radicals (Pigeolet et al., 1990).

Catalase activity increased significantly in the WPH groups but was substantially lower in the paracetamol group compared with the control group (Table 2). The increase was highest in the curative group (193.66 \pm $18.61 \mathrm{U} / \mathrm{mg}$ of protein) but still significantly lower than in the control $(214.28 \pm 7.92 \mathrm{U} / \mathrm{mg}$ of protein). Similarly, GSHPx activity increased significantly in groups fed or injected with WPH compared with the paracetamol group, although again the values in the treatment groups were lower than in the control group. Activity of GSHPx was significantly higher in all WPHtreated groups compared with the paracetamol group $(1.22 \pm 0.49 \mathrm{U} / \mathrm{mg}$ of protein) and similar to that of control groups $(2.1 \pm 0.38 \mathrm{U} / \mathrm{mg}$ of protein; Table 2$)$. Similar results were reported by Yadav et al. (2011), when heat-denatured whey protein (HDWP) and its hydrolysates were fed to mice along with oxidized oil. The elevation in antioxidant enzyme activities of mice fed the hydrolysates was greater than that seen when feeding HDWP. This may be due to the substantially high antioxidant capacity of hydrolysates compared with HDWP. It has been suggested that whey proteins donate hydrogen to decrease the number of free radicals and free sulfhydryl groups from cysteine, which are effective at inhibiting lipid autoxidation (Richardson and Korycka-Dahl, 1983). The effect of various diets containing antioxidants on antioxidant enzymes has been studied by several researchers recently. Nevin and Rajamohan (2006) observed that virgin coconut oil with more unsaponifiable components (e.g., vitamin E and polyphenols) than copra oil exhibited increased levels of antioxidant enzymes and prevented the peroxidation of lipids both in vitro and in vivo, showing that virgin coconut oil containing natural antioxidants was superior in antioxidant action than copra oil and groundnut oil.

The antioxidants present in tea extracts also elevated the activity of antioxidant enzymes. Green tea polyphenols significantly inhibited UV-induced decreases in epidermal CAT and glutathione reductase. Oral administration of black or green tea extract resulted in increased serum SOD activity in mice exposed to the carcinogen 3-methyleolanthrene. Rats provided with green tea extract exhibited attenuation of ethanol-associated decrease in CAT, SOD, and GSHPx activities in serum and liver (Frei and Higdon, 2003).

Levels of TBARS, a measure of lipid peroxidation expressed as increased malondialdehyde formation, are presented in Table 2. Malondialdehyde is a marker of oxidative lipid damage and is major oxidative product of

Table 2. The activity of endogenous antioxidant enzymes such as catalase (CAT), superoxide dismutase (SOD), glutathione peroxidase (GSHPx), and levels of thiobarbituric acid reactive substances (TBARS) in the liver homogenate of different groups of mice ${ }^{1}$

\begin{tabular}{|c|c|c|c|c|c|}
\hline \multirow[b]{2}{*}{ Parameter $^{2}$} & \multirow[b]{2}{*}{ Control } & \multirow[b]{2}{*}{ Paracetamol } & \multicolumn{2}{|c|}{ Intraperitoneal injection } & \multirow[b]{2}{*}{ Oral } \\
\hline & & & Preventive & Curative & \\
\hline CAT & $214.28 \pm 7.92^{\mathrm{d}}$ & $149.67 \pm 12.83^{\mathrm{a}}$ & $170.84 \pm 5.86^{\mathrm{b}}$ & $193.66 \pm 18.61^{\mathrm{c}}$ & $157.82 \pm 7.92^{\mathrm{a}}$ \\
\hline SOD & $6.81 \pm 0.45^{\mathrm{b}}$ & $5.58 \pm 0.38^{\mathrm{a}}$ & $6.67 \pm 0.09^{\mathrm{b}}$ & $6.92 \pm 0.91^{\mathrm{b}}$ & $6.24 \pm 0.91^{\mathrm{ab}}$ \\
\hline GSHPx & $2.1 \pm 0.38^{\mathrm{c}}$ & $1.22 \pm 0.49^{\mathrm{a}}$ & $1.95 \pm 0.56^{\mathrm{bc}}$ & $1.79 \pm 0.49^{\mathrm{b}}$ & $1.86 \pm 0.29^{\mathrm{b}}$ \\
\hline TBARS & $30.36 \pm 2.56^{\mathrm{a}}$ & $80.57 \pm 8.99^{\mathrm{b}}$ & $34.79 \pm 0.58^{\mathrm{a}}$ & $34.19 \pm 1.92^{\mathrm{a}}$ & $35.11 \pm 6.29^{\mathrm{a}}$ \\
\hline
\end{tabular}

${ }^{\mathrm{a}-\mathrm{d}}$ Means within a row with different superscripts differ $(P<0.05)$.

${ }^{1}$ Control $=$ untreated control mice; paracetamol = mice overdosed with paracetamol at a $300 \mathrm{mg} / \mathrm{kg}$ of BW for $2 \mathrm{~d}$; intraperitoneal injection = whey protein hydrolysate (WPH) administered by intraperitoneal injection at $4 \mathrm{mg} / \mathrm{kg}$ of BW for $4 \mathrm{~d}$ before (preventive) or $4 \mathrm{~d}$ after (curative) paracetamol administration; oral $=\mathrm{WPH}$ given orally at $8 \mathrm{mg} / \mathrm{kg}$ of BW for $4 \mathrm{~d}$ before paracetamol administration.

${ }^{2} \mathrm{CAT}$, SOD, and GSHPx expressed in $\mathrm{U} / \mathrm{mg}$ of protein; TBARS expressed in $\mu \mathrm{mol}$ of malondialdehyde/mg of protein. 
peroxidized PUFA. As can be seen in Table 2, the levels of TBARS increased significantly in liver homogenate of the paracetamol group compared with the control group ( $80.57 \pm 8.99$ vs. $30.36 \pm 2.56 \mu \mathrm{mol}$ of malondialdehyde/mg of protein, respectively). The elevation in TBARS is an indicator of lipid peroxidation, which is closely related to paracetamol-induced tissue damage (Sener et al., 2003). On oral and intraperitoneal administration of WPH, the level of TBARS decreased to normal levels, comparable to that of the control group (Table 2). It has been proven that hydrogen peroxide and superoxide anions are produced during metabolic activation of paracetamol in the CYP 450 system (Dai and Cederbaum, 1995). A wide variety of oxidizing molecules, such as ROS, or depleting agents can alter the GSH redox state, which is normally maintained by the activity of GSH-depleting (GSHPx and GST) and GSH-replenishing (glutathione reductase) enzymes (Halliwell, 1996). Therefore, it can be assumed that the decrease in GSH concentration might restrict the effectiveness of GST and GSHPx activities, which is indicated by the intensification of lipid peroxidation (Czeczot et al., 2006). Antioxidant enzymes can also be inactivated by lipid peroxides and ROS (Halliwell and Gutteridge, 1984). All of these reports indicate the relationship between the level of TBARS and the activities of antioxidant enzymes. Similarly, we observed an increase in activities of antioxidant enzymes SOD, CAT, and GSHPx in all groups treated with WPH with the decrease in lipid peroxidation (i.e., the levels of TBARS). It may be accomplished that the WPH with high antioxidant activity due the presence of antioxidant peptides in it (Hernandez-Ledesma et al., 2005; Yadav et al., 2011), which acted like other natural antioxidants such as vitamin E, riboflavin and polyphenols (Frei and Higdon, 2003; Nevin and Rajamohan, 2006). These WPH might have inactivated hydrogen peroxide and superoxide anion, which are produced during metabolic activation of paracetamol in the CYP 450 system (Dai and Cederbaum, 1995), and restored the antioxidant defense system in the experimental mice.

\section{CONCLUSIONS}

Whey protein hydrolysate had a considerable protective effect on hepatic damage induced by paracetamol. The WPH not only possessed effective protective action but also curative action. It mitigated the toxicity of paracetamol by different pathways such as decreasing the concentrations of oxidative biomarkers GPT, ALP, creatinine, and TBARS levels and increasing the total antioxidant potential of hepatocytes by restoring the levels of BUN and activities of antioxidant enzymes CAT, SOD, and GSHPx. Further studies are needed to determine the exact mechanism of action of administration of WPH in protection against liver and kidney damage.

\section{REFERENCES}

Adriena, D. K., P. Anne, M. Pertti, C. Ladislav, and J. T. K. Hannu. 2010. Antioxidant properties of whey protein hydrolysates as measured by three methods. Eur. Food Res. Technol. 230:865-874.

Aebi, H. 1984. Catalase in vitro. Pages 121-126 in Methods in Enzymology. Vol. 105. L. Packer, ed., Academic Press, New York, NY.

Ahmed, A. E., A. S. Hafiza, S. G. Ahmed, A. M. Fathia, S. H. Nabila, and A. A. Mosaad. 2010. Whey protein concentrate and ginseng extract exhibit antioxidant properties in vitro and reduce hepatotoxicity and oxidative stress of aflatoxin in vivo. New York Sci. J. $3: 37-51$.

Athira, S. 2012. Process optimization for the production of bioactive peptides enriched ingredients from cheese whey. Master's Thesis. National Dairy Research Institute, Karnal, India.

Bones, R. W., and H. H. Tausky. 1945. Colorimetric determination of creatinine by the Jaffe reaction. J. Biol. Chem. 158:581-591.

Bowers, L. D. 1980. Creatinine (serum) assay kit. Clin. Chem. 26:551-554.

Crocker, C. L. 1967. Rapid determination of urea nitrogen in serum or plasma without deproteinisation. Am. J. Med. Technol. 33:361365.

Czeczot, H., S. Dorota, S. Michał, and P. Małgorzata. 2006. Glutathione and GSH-dependent enzymes in patients with liver cirrhosis and hepatocellular carcinoma. Acta Biochim. Pol. 53:237-242.

Dahlin, D. C., G. T. Miwa, A. Y. Lu, and S. D. Nelson. 1984. N-Acetyl p-benzoquinimine: A cytochrome P450 mediated oxidation product of acetaminophen. Proc. Natl. Acad. Sci. USA 81:1327-1331.

Dai, Y., and A. I. Cederbaum. 1995. Cytotoxicity of acetaminophen in human cytochrome P450 2E1-transfected HepG2 cells. J. Pharmacol. Exp. Ther. 273:1497-1505.

Fang, Y. Z., S. Yang, and G. Wu. 2002. Free radicals, antioxidants and nutrition. Nutrition 18:872-879.

Frei, B., and J. V. Higdon. 2003. Antioxidant activity of tea polyphenols in vivo: Evidence from animal studies. J. Nutr. 133:3275S$3284 \mathrm{~S}$.

Ghosh, A., and P. C. Sil. 2007. Anti-oxidative effect of a protein from Cajanus indicus L. against acetaminophen-induced hepato-nephro toxicity. J. Biochem. Mol. Biol. 40:1039-1049.

Ghosh, J., J. Das, P. Manna, and P. C. Sil. 2010. Acetaminophen induced renal injury via oxidative stress and TNF-alpha production: Therapeutic potential of arjunolic acid. Toxicology 268:8-18.

Gregory, C. R. 2003. Urinary system. Pages 250-253 in Veterinary Laboratory Medicine: Clinical Pathology. 4th ed. K. S. Latimer, E. A. Mahaffey, and K. W. Prasse, ed. Iowa State University Press, Ames.

Halliwell, B. 1996. Antioxidants in human health and disease. Annu. Rev. Nutr. 16:33-50.

Halliwell, B., and J. M. Gutteridge. 1984. Oxygen toxicity, oxygen radicals, transition metals and disease. Biochem. J. 219:1-14.

Hernandez-Ledesma, B., A. Davalos, B. Bartolome, and L. Amigo. 2005. Preparation of antioxidant enzymatic hydrolysates from $\alpha$-lactalbumin and $\beta$-lactoglobulin. Identification of active peptides by HPLC-MS/MS. J. Agric. Food Chem. 53:588-593.

Jaeschke, H., T. R. Knight, and M. L. Bajt. 2003. The role of oxidant stress and reactive nitrogen species in acetaminophen hepatotoxicity. Toxicol. Lett. 144:279-288.

Kind, P. R. N., and E. J. King. 1954. Estimation of plasma phosphatase by determination of hydrolyzed phenol with antipyrine. J. Clin. Pathol. 7:322-326.

Lawrence, R. A., and R. F. Burk. 1976. Glutathione peroxidase activity in selenium-deficient rat liver. Biochem. Biophys. Res. Commun. 71:952-958.

Lee, E. S., H. E. Lee, J. Y. Shin, S. Yoon, and J. O. Moon. 2003. The flavonoid quercetin inhibits dimethylnitrosamine-induced liver damage in rats. J. Pharm. Pharmacol. 55:1169-1174. 
Lowry, O. H., N. F. Rosebrough, A. L. Farr, and R. J. Randall. 1951. Protein measurement with the Folin phenol reagent. J. Biol. Chem. 193:265-275.

Lynch, G. P., W. T. Shalkop, N. M. Jacoby, D. F. Smith, and R. W Miller. 1971. Responses of dairy calves to oral doses of aflatoxin. J. Dairy Sci. 54:1688-1698.

Marklund, S., and S. Marklund. 1974. Involvement of superoxide dismutase anion radical in autooxidation of pyrogallol and a convenient assay for superoxide dismutase. Eur. J. Biochem. 42:469474 .

Marsh, W. H., B. Fingerhut, and H. Miller. 1965. Automated and manual direct methods for the determination of blood urea. Clin. Chem. 11:624-627.

Michael, S. L., N. R. Pumford, P. R. Mayeux, M. R. Niesman, and J. A. Hinson. 1999. Pretreatment of mice with macrophage inactivators decreases acetaminophen hepatotoxicity and the formation of reactive oxygen and nitrogen species. Hepatology 30:186-195.

Mitchell, J. R., D. J. Jollow, W. Z. Potter, J. R. Gillete, and B. B. Brodie. 1973. Acetaminophen induced hepatic necrosis. Protective role of glutathione. J. Pharmacol. Exp. Ther. 187:211-217.

Mladenovic, D., T. Radosavljevic, M. Ninkovic, D. Vucevic, R. JesicVukicevic, and V. Todorovic. 2009. Liver antioxidant capacity in the early phase of acute paracetamol-induced liver injury in mice. Food Chem. Toxicol. 47:866-870.

Moskovitz, J., M. B. Yim, and P. B. Choke. 2002. Free radicals and disease. Arch. Biochem. Biophys. 397:354-359.

Moure, A., H. Dominguez, and J. C. Parajo. 2006. Antioxidant properties of ultrafiltration-recovered soy protein fractions from industrial effluents and their hydrolysates. Process Biochem. 41:447-456.

Nevin, K. G., and T. Rajamohan. 2006. Virgin coconut oil supplemented diet increases the antioxidant status in rats. Food Chem. 99:260-266.

Newton, J., D. Hoefle, M. Gemborys, G. Mugede, and J. Hook. 1986. Metabolism and excretion of a glutathione conjugate of acetaminophen in the isolated rat kidney. J. Pharmacol. Exp. Ther. 237:519-524.

Parmar, S. R., H. V. Patel, and K. Kiran. 2010. Hepatoprotective activity of some plants extract against paracetamol induced hepatotoxicity in rats. J. Herb. Med. Toxicol. 4:101-106.

Pigeolet, E., P. Corbisier, A. Houbion, D. Lambert, C. Michiels, M. Raes, M. D. Zacgary, and J. Remacle. 1990. Glutathione peroxidase, superoxide dismutase, and catalase inactivation by peroxides and oxygen derived free radicals. Mech. Ageing Dev. 51:283-297.

Proudfoot, A. T., and N. Wright. 1970. Acute paracetamol poisoning. BMJ 3:557-558.

Qian, Z. J., W. K. Jung, and S. K. Kim. 2008. Free radical scavenging activity of a novel antioxidative peptide purified from hydrolysates of bull frog skin Rana catesbeiana Shaw. Bioresource Technol. 99:1690-1698.
Rajapakse, N., E. Mendis, W. K. Jung, J. Y. Je, and S. K. Kim. 2005. Purification of a radical scavenging peptide from fermented mussel sauce and its antioxidant properties. Food Res. Int. 38:175-182.

Reitman, S., and S. A. Franke. 1957. A colorimetric method for the determination of serum glutamic oxaloacetic and glutamic pyruvic transminases. Am. J. Clin. Pathol. 28:56-63.

Richardson, T., and M. Korycka-Dahl. 1983. Lipid oxidation. Pages 244-309 in Developments in Dairy Chemistry. Vol.2. P. F. Fox, ed. Elsevier Applied Science, London, UK.

Sener, G., A. O. Sehirli, and G. Ayanog lu-Dulger. 2003. Protective effects of melatonin, vitamin $\mathrm{E}$ and $N$-acetylcysteine against acetaminophen toxicity in mice. A comparative study. J. Pineal Res. 35:61-68.

Singh, S., K. Shanker, K. Mritunjay, C. Kalpana, and R. Singh. 2011. Ameliorative potential of quercetin against paracetamol-induced oxidative stress in mice blood. Toxicol. Int. 18:140-145.

Stockham, S. L., and M. A. Scott. 2002. Pages 438, 446-450 in Fundamentals of Veterinary Clinical Pathology. Iowa State University Press, Ames.

Trumper, L., L. A. Monasterolo, and M. M. Elias. 1998. Probenecid protects against in vivo acetaminophen-induced nephrotoxicity in male Wistar rats. J. Pharmacol. Exp. Ther. 284:606-610.

Mihara, M., and M. Uchiyama. 1978. Determination of malondialdehyde precursor in tissues by thiobarbituric acid test. Anal. Biochem. 86:271-278.

Wang, C. S., T. T. Chang, W. J. Yao, S. T. Wang, and P. Chou. 2012. Impact of increasing alanine aminotransferase levels within normal range on incident diabetes. J. Formos. Med. Assoc. 111:201-208.

Waring, W. S., A. F. Stephen, O. D. Robinson, M. A. Dow, and J. Pettie. 2008. Serum urea concentration and the risk of hepatotoxicity after paracetamol overdose. QJM 101:359-363.

Watanabe, A., K. Okada, Y. Shimizu, H. Wakabayashi, K. Higuchi, and K. Niiya. 2000. Nutritional therapy of chronic hepatitis by whey protein (non-heated). J. Med. 31:283-302.

Xinyan, P., L. X. Youling, and K. Baohua. 2009. Antioxidant activity of peptide fractions from whey protein hydrolysates as measured by electron spin resonance. Food Chem. 113:196-201.

Yadav, N., B. Mann, P. Saini, and R. Kumar. 2011. Antioxidant properties of whey protein hydrolysates prepared using heat denatured whey proteins. Milchwissenchaft 66:67-70.

Yousef, M. I., S. A. Omar, M. I. El-Guendi, and L. A. Abdelmegid 2010. Potential protective effects of quercetin and curcumin on paracetamol-induced histological changes, oxidative stress, impaired liver and kidney functions and haematotoxicity in rat. Food Chem. Toxicol. 48:3246-3261.

Zeinab, A. S., A. E. Gamaal, F. Garawany, F. Assem, and E. Safinaz. 2007. Evaluation of the efficacy of whey protein to ameliorate the toxic effects of aflatoxins in rats. Int. Dairy J. 17:854-859. 